\title{
Novel s-triazine-degrading bacteria isolated from agricultural soils of central Chile for herbicide bioremediation
}

\author{
Marcela Hernández García \\ Programa de Doctorado en Ciencias de Recursos Naturales \\ Universidad de La Frontera, Temuco \\ Laboratorio de Microbiología Molecular y Biotecnología Ambiental \\ Millennium Nucleus of Microbial Ecology and \\ Environmental Microbiology and Biotechnology \\ Departamento de Química \\ Universidad Técnica Federico Santa María \\ Av. España 1680, Valparaíso, Chile \\ Tel: 56322654236 \\ Fax: 56322654782 \\ E-mail:mthernan@ufro.cl

\section{Verónica Morgante} \\ Laboratorio de Microbiología Molecular y Biotecnología Ambiental \\ Millennium Nucleus of Microbial Ecology and \\ Environmental Microbiology and Biotechnology \\ Departamento de Química \\ Universidad Técnica Federico Santa María \\ Av. España 1680, Valparaíso, Chile \\ Tel: 56322654236 \\ Fax: 56322654782 \\ E-mail: veronica.morgante@gmail.com
}

\section{Marcela Ávila Perez}

Laboratorio de Microbiología Molecular y Biotecnología Ambiental Millennium Nucleus of Microbial Ecology and

Environmental Microbiology and Biotechnology

Departamento de Química

Universidad Técnica Federico Santa María

Av. España 1680, Valparaíso, Chile

Tel: 56322654236

Fax: 56322654782

E-mail: avila@science.uva.nl

\section{Patricio Villalobos Biaggini}

Laboratorio de Microbiología Molecular y Biotecnología Ambiental

Millennium Nucleus of Microbial Ecology and

Environmental Microbiology and Biotechnology

Departamento de Química

Universidad Técnica Federico Santa María

Av. España 1680, Valparaíso, Chile

Tel: 56322654236

Fax: 56322654782

E-mail: patricio.villalobos@usm.cl

\section{Pola Miralles Noé}

Laboratorio de Microbiología Molecular y Biotecnología Ambiental

Millennium Nucleus of Microbial Ecology and

Environmental Microbiology and Biotechnology

Departamento de Química

Universidad Técnica Federico Santa María

Av. España 1680, Valparaíso, Chile

Tel: 56322654236

Fax: 56322654782

E-mail: pola_miralles@yahoo.es

\section{Myriam González Vergara}

Laboratorio de Microbiología Molecular y Biotecnología Ambiental

Millennium Nucleus of Microbial Ecology and

Environmental Microbiology and Biotechnology

Departamento de Química 


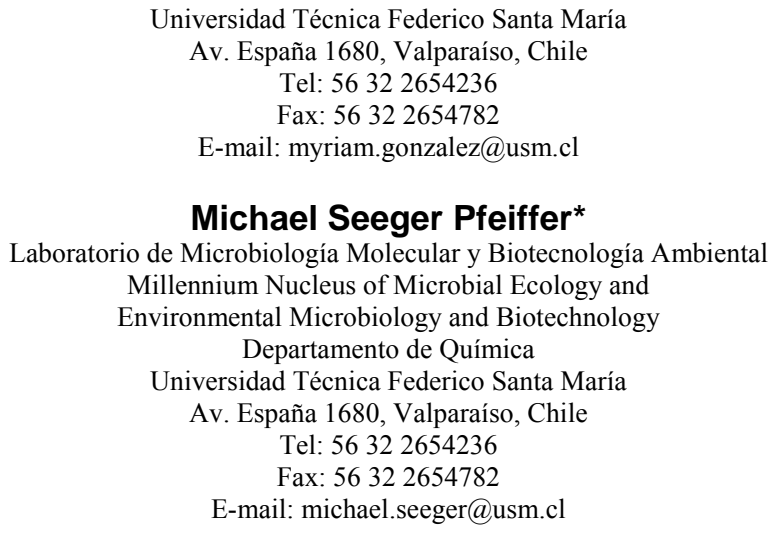

Present address: "Laboratory for Molecular Microbial Physiology. Swammerdam Institute for Life Sciences, Nieuwe Achtergracht 166, 1018 WV Amsterdam, The Netherlands, Tel: 3120 5257053, Fax: 3120 5257056, E-mail: avila@science.uva.nl.

Financial support: MS acknowledges financial support from Millennium Nucleus EMBA P04/007-F, ICA4-CT-2002-10011 (European Union), USM 130522 and USM 130836 grants. MH, VM and PV acknowledge CONICYT and MECESUP-UCV-0206 fellowships.

Keywords: Arthrobacter, biodegradation, bioremediation, simazine, Stenotrophomonas, s-triazine.

Abbreviations: AM: atrazine medium

ARDRA: amplified ribosomal DNA restriction analysis

CFU: colony forming unit

LB: Luria Bertani

PCR: polymerase chain reaction

TSA: tryptic soy agar
$s$-Triazine-degrading bacterial strains were isolated from long-term simazine-treated agricultural soils of central Chile. The number of culturable heterotrophic bacteria of these agricultural soils $\left(7 \times 10^{6} \mathrm{CFU} / \mathrm{g}\right.$ of dry soil) was not affected by simazine application on field. The simazine-degrading bacterial strains P51, P52 and C53 were isolated by enrichment in minimal medium using simazine as the sole nitrogen source. Resting cells of strains P51 and P52 degraded $>\mathbf{8 0} \%$ of simazine within 48 hrs, whereas strain C53 was able to remove $>60 \%$ of the herbicide. The atzA and $a t z D$ genes of the $s$ triazine upper and lower catabolic pathways were detected in strains P51 and C53, while only atzD gene was observed in strain P52. To compare the bacterial 16S rRNA gene sequence structure, ARDRA were performed using the restriction enzymes Msp1 and Hha1. ARDRA indicated that strain P52 was a different ribotype than $\mathrm{C} 53$ and $\mathrm{P} 51$ strains. For further characterization the novel isolates were identified by $16 S$ rRNA gene sequencing. Strains C53 and P51 belong to the genus Stenotrophomonas and the strain P52 belongs to the genus Arthrobacter. $s$-Triazine-degrading bacterial strains isolated from contaminated soils could be used as biocatalysts for bioremediation of these herbicides.

Soil decontamination is one of the main environmental challenges for the third millennium to safeguard the planet. The herbicides are the most abundant agrochemicals used worldwide and their application has increased in the last decades. The United States is the main herbicide consumer, with an annual application of around 205,000 tons (Kiely et al. 2004). The European Union registered an annual consumption of around 130,000 tons of herbicides between 1990 and 2000 (FAO, 2006), wherein France (26\%), United Kingdom (17\%) and Italy (12\%) head the herbicide usage. In South America, the annual use of herbicides was around 60,000 tons between 1990 and 2000 (Figure 1). Brazil $(38 \%)$, Argentina (28\%) and Colombia (18\%) are the main herbicide consumers in South America.

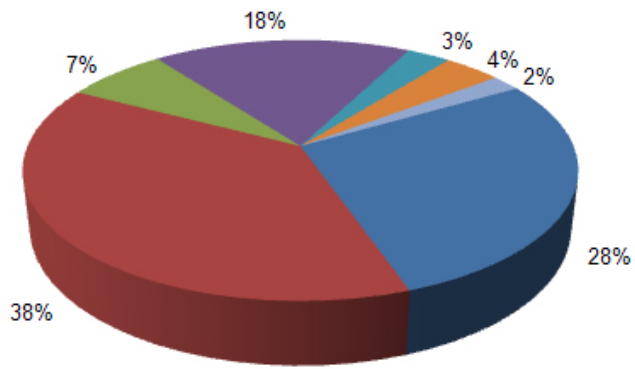

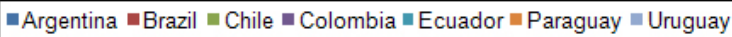

Figure 1. South America's herbicide consumption from 1990 to 2001. Food and Agriculture Organization of the United Nations, 2006. Statistical database, FAO, Rome, Italy.

*Corresponding author 


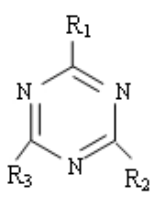

\begin{tabular}{|l|c|l|l|}
\hline \multicolumn{1}{|c|}{ s-Triazine } & $\mathbf{R}_{\mathbf{1}}$ & \multicolumn{1}{c|}{$\mathbf{R}_{\mathbf{2}}$} & \multicolumn{1}{c|}{$\mathbf{R}_{\mathbf{3}}$} \\
\hline Atrazine & $\mathrm{Cl}$ & $\mathrm{NHC}_{2} \mathrm{H}_{5}$ & $\mathrm{NHCH}\left(\mathrm{CH}_{3}\right)_{2}$ \\
\hline Cianazine & $\mathrm{Cl}$ & $\mathrm{NHC}(\mathrm{CN})\left(\mathrm{CH}_{3}\right)_{2}$ & $\mathrm{NHCH}\left(\mathrm{CH}_{3}\right)_{2}$ \\
\hline Propazine & $\mathrm{Cl}$ & $\mathrm{NHCH}\left(\mathrm{CH}_{3}\right)_{2}$ & $\mathrm{NHCH}\left(\mathrm{CH}_{3}\right)_{2}$ \\
\hline Simazine & $\mathrm{Cl}$ & $\mathrm{NHC}_{2} \mathrm{H}_{5}$ & $\mathrm{NHC} \mathrm{H}_{5}$ \\
\hline
\end{tabular}

Figure 2. Chemical structures of $s$-triazines. Members of $s$ triazine herbicides differ by their $R_{1}, R_{2}$ y $R_{3}$ groups the $s$ triazine ring.

$s$-Triazine compounds have been used for weed control in many countries for more than 40 years (Wackett et al. 2002; Dinamarca et al. 2007). These synthetic and chlorinated herbicides (Figure 2) inhibit the photosynthetic electron transfer in target plants (Rousseaux et al. 2001). sTriazines have been applied as pre- and post-emergence herbicides for broadleaf and grassy weed control in corn, citrus, alfalfa, grapes, avocado and olives crops (Wackett et al. 2002; Cooman et al. 2005). Their non-agricultural uses include weed control on right-of-ways, ornamental trees and golf fairways. In 2001, the European Union reported a list of "priority hazardous substances" (European Union, 2001). Atrazine and simazine have been included in this list due to their persistence, toxicity, moderate leaching capacity and potential to adsorb onto soils and sediments. Commonly, s-triazine herbicides detected in water exceed the maximum contaminant levels allowed for drinking water in European Union $(0.1 \mu \mathrm{g} / \mathrm{l})$ and USA $(3.0 \mu \mathrm{g} / \mathrm{l})$ (Rousseaux et al. 2001). Although s-triazines have been prohibited in many European countries, in Chile there are no restrictions for their use and atrazine and simazine are the most frequently applied herbicides in agriculture and forestry. s-Triazine consumption in Chile was around 350 tons during 2004 (Dinamarca et al.2007), which represents $10 \%$ of the herbicide usage. s-Triazine herbicides have been recently detected as contaminants in agricultural watersheds in south-central Chile (Cooman et al. 2005).
Degradation by microorganisms is the primary removal mechanism of $s$-triazine herbicides from the soil (Newcombe and Crowley, 1999; Dinamarca et al. 2007; Hernández et al. 2008a). For environmental bioremediation, the isolation of microorganisms capable of degrading the target pollutant is important. A number of s-triazinedegrading bacteria have been described (Mandelbaum et al. 1995; Devers et al. 2007; Hernández et al. 2008b). The bacterial enzymes for $s$-triazine degradation are encoded by $a t z A, a t z B, a t z C, a t z D, a t z E$ and $a t z F$ genes (Figure 3) (de Souza et al. 1998; Martínez et al. 2001; Iwasaki et al. 2007).

The aim of this study was to isolate novel bacterial strains capable to degrade s-triazines from agricultural soils in the Quillota valley, central Chile. For enrichment and isolation of bacterial strains, long-term simazine treated soils were used. Physiological, biochemical and molecular studies were carried out to characterize and identify bacterial isolates, which could be used as novel biocatalysts for soil bioremediation.

\section{MATERIALS AND METHODS}

\section{Materials}

Commercial simazine (Gesatop WP90) was purchased from Syngenta (Greensboro, United States). Simazine (99\% pure) and standard simazine ( $>99 \%$ pure) were obtained from Atanor (Buenos Aires, Argentina) and Dr. Ehrensdorfer-Schäfers $\mathrm{GmbH}$ (Augsburg, Germany), respectively.

\section{Soil sampling}

Soil were sampled from agricultural sites in Quillota valley, central Chile. The sampling sites were an avocado (Persea americana) and a persimmon (Diospyros chinensis) plantations that have been annually treated with commercial simazine for more than 20 years, according to farming practices for the control of annual weeds. Soil samples were collected in December 2002 from the top soil stratum $(0-20 \mathrm{~cm})$. Samples were sieved, air dried and stored at $4^{\circ} \mathrm{C}$.

Table 1. Biochemical and physiological characterization of the novel bacterial strains isolated from agricultural soil.

\begin{tabular}{|c|c|c|c|c|}
\hline Strain & Gram & Catalase & Oxidase & Motility \\
\hline P51 & - & + & - & + \\
\hline P52 & + & + & - & - \\
\hline C53 & - & + & - & + \\
\hline
\end{tabular}




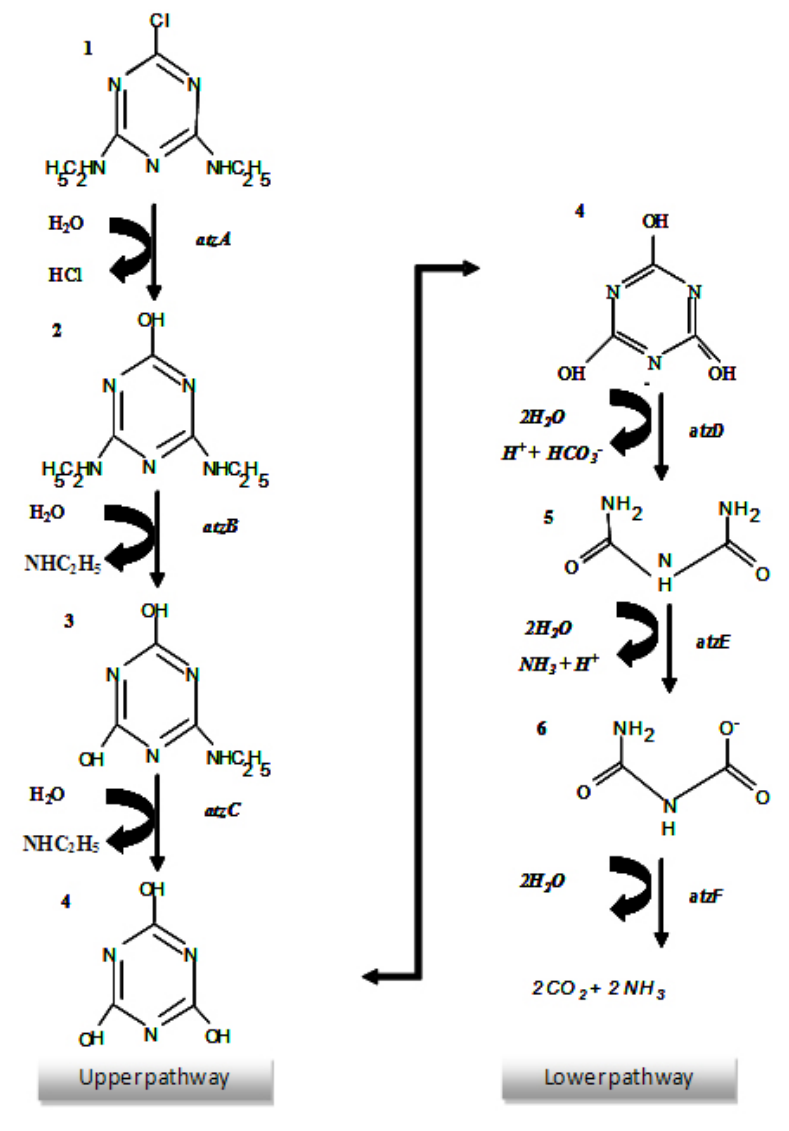

Figure 3. The simazine catabolic upper and lower pathways. The catabolic atz gene encoding the respective enzyme is indicated at each metabolic step. Pathways substrates and metabolites: 1 . Simazine; 2 . Hydroxysimazine; 3. N-etilammelide; 4. Cyanuric acid; 5. Biuret; 6. Allophanate.

\section{Isolation of herbicide-degrading bacteria}

The isolation of native simazine-degrading bacterial strains was performed by batch enrichment cultivation. $10 \mathrm{~g}$ of soil (dry weight basis) was inoculated in $90 \mathrm{ml}$ of atrazine medium (AM) (Rousseaux et al. 2001), using commercial simazine as sole nitrogen source. Cycloheximide $(50 \mathrm{mg} / \mathrm{l})$ was added to the medium to inhibit eukaryotic cell growth. Cultures were incubated at $28^{\circ} \mathrm{C}$ with orbital agitation. Enrichment cultures were subcultured and isolates were obtained by spread plating on AM agar with simazine (2.5 $\mathrm{mM}$ ). Colonies on AM agar were purified and maintained on this medium. Strains were stored at $-24^{\circ} \mathrm{C}$. The culturable heterotrophic bacteria of soils were estimated by plating on tryptic soy agar (TSA) plates.

\section{Physiological and biochemical characterization}

The isolates were characterized by conventional methods: Gram staining, catalase and oxidase activities and motility.
The morphology of bacterial colonies on TSA plates was observed. The bacterial growth in Luria Bertani (LB) broth (tryptone $10 \mathrm{~g} / \mathrm{l}$, yeast extract $5 \mathrm{~g} / \mathrm{l}, \quad \mathrm{NaCl} \quad 5 \mathrm{~g} / \mathrm{l}$ ) supplemented with simazine $(2.5 \mathrm{mM})$ was determined by measuring turbidity at $600 \mathrm{~nm}$. For electron microscopy, bacterial cells grown in AM medium with simazine were treated and observed with a Zeiss EM900 electron microscope as described previously (Cámara et al. 2004).

\section{Analysis of simazine degradation}

Cells grown in LB broth supplemented with simazine at $30^{\circ} \mathrm{C}$ until exponential phase, were washed and resuspended in $10 \mathrm{mM}$ sodium phosphate buffer ( $\mathrm{pH} 7.0)$ to a turbidity ${ }_{600 \mathrm{~nm}}$ of $\sim 5$. Resting cells were incubated with simazine ( $0.5 \mathrm{mM})$ for $48 \mathrm{hrs}$.

Simazine was extracted with isooctane and quantified using high-performance liquid chromatography (HPLC) (Martínez et al. 2007; Hernández et al. 2008b). Samples were analyzed using a Beckman liquid chromatograph equipped with a diode array detector and a RPC18/Lichrospher 5- $\mu \mathrm{m}$ column (Supelco, Bellefonte, USA). The chromatograph was operated at room temperature and UV detection at $230 \mathrm{~nm}$. The samples were eluted at a flow rate of $0.5 \mathrm{ml} / \mathrm{min}$ using a mobile phase containing $67 \%$ $(\mathrm{v} / \mathrm{v})$ acetonitrile, $32.5 \%(\mathrm{v} / \mathrm{v})$ water and $0.5 \%(\mathrm{v} / \mathrm{v})$ phosphoric acid (pH 2.0). The flow rate was $1 \mathrm{ml} / \mathrm{min}$. Simazine was identified and quantified by comparison with an authentic standard.

\section{Analysis of catabolic atz genes}

The atzA and $a t z D$ genes were amplified by polymerase chain reaction (PCR) using specific primers as described (de Souza et al. 1998; Devers et al. 2004). Genomic DNA was prepared from single colonies resuspended in $100 \mu \mathrm{l}$ Tris-EDTA buffer, heated at $95^{\circ} \mathrm{C}$ for $5 \mathrm{~min}$ and centrifuged briefly. The supernatant $(2.0 \mu \mathrm{l})$ was used for PCR $(25 \mu$ final volume).

\section{Amplified ribosomal DNA restriction analysis (ARDRA)}

Genomic DNA was isolated from a single colony grown overnight in LB broth by using Wizard genomic kit (Promega, Madison, WI, USA). 16S rRNA genes were amplified using primers $27 \mathrm{f}$ (5'AGAGTTTGATCMTGGCTCAG-3') and 1492r (5'TACGGYTACCTTGTTACGACTT-3') and Taq polymerase (Invitrogen, Carlsbad, CA, USA ). PCR amplification were carried out using the following conditions: 1 cycle of $94^{\circ} \mathrm{C}$ for $3 \mathrm{~min}, 30$ cycles of $94^{\circ} \mathrm{C}$ for $30 \mathrm{sec}, 55^{\circ} \mathrm{C}$ for $30 \mathrm{sec}, 72^{\circ} \mathrm{C}$ for $45 \mathrm{sec}$, plus a final extension at $72^{\circ} \mathrm{C}$ for $7 \mathrm{~min}$. The PCR products were digested with the endonucleases MspI and HhaI (Promega, Madison, WI, USA), according to the protocols of the manufacturer. ARDRA profiles $(5 \mu 1$ of digested $16 \mathrm{~S}$ rRNA gene products) were visualized under UV light in a $3 \%$ agarose gel stained with ethidium bromide. 
Table 2. Bacterial characterization by $16 \mathrm{~S}$ rRNA gene sequence analysis and PCR-amplification of atzA and atzD genes.

\begin{tabular}{|c|c|c|c|c|}
\hline Strain & Identification (16S rRNA) & Similarity (\%) & atzA gene & atzD gene \\
\hline P51 & Stenotrophomonas & $>98$ & + & + \\
\hline P52 & Arthrobacter & $>97$ & - & + \\
\hline C53 & Stenotrophomonas & $>99$ & + & + \\
\hline
\end{tabular}

\section{Identification of bacterial strains by $16 \mathrm{~S}$ rRNA gene sequence analysis}

DNA was extracted using the BIO101 DNA kit for bacteria (Qiagen, Hilden, Germany). For PCR amplification of $16 \mathrm{~S}$ rRNA genes, the 27f and 1492r primers were used. Amplification reaction was performed with a DNA Engine PTC-200 Peltier Thermal Cycler (MJ Research, Massachusetts, USA), with the following program: 1 cycle of $95^{\circ} \mathrm{C}$ for $5 \mathrm{~min} ; 35$ cycles of $95^{\circ} \mathrm{C}$ for $45 \mathrm{sec} ; 55^{\circ} \mathrm{C}$ for 45 sec; $72^{\circ} \mathrm{C}$ for $2 \mathrm{~min}$; followed by a final extension at $72^{\circ} \mathrm{C}$ for $10 \mathrm{~min}$. Amplification products were visualized after separation by electrophoresis in a $1 \%$ agarose gel and staining with ethidium bromide. PCR 16S rRNA genes were purified, using QiaQuick columns and the protocol of the manufacturer (Qiagen, Hilden, Germany), and sequenced directly, using a Taq DyeDeoxy Terminator Cycle Sequencing kit, version 3.1, an ABI model 3100 DNA Sequencer and the protocols of the manufacturer (Applied Biosystems Inc., Foster City, CA, USA).

\section{RESULTS AND DISCUSSION}

\section{Isolation of $s$-triazine-degrading bacteria}

The adaptation to long-term polluted environmental sites endows environmental microbes with the catabolic capabilities for these pollutants. Agricultural so ils treated with the herbicide simazine for more than 20 years were used for isolation of bacterial strains able to degrade $s$ triazines. The number of culturable heterotrophic bacteria from these agricultural soils was $7 \times 10^{6} \mathrm{CFU} / \mathrm{g}$ of dry soil. This number was not affected by simazine application. Microbial communities from these soils were enriched under aerobic conditions in AM broth using simazine as sole nitrogen source. Three bacterial isolates capable of simazine-degradation were selected and characterized. Strains P51 and P52 were isolated from an avocado plantation soil, and strain C53 was isolated from a persimmon plantation soil. The bacterial strains were characterized by biochemical and physiological analyses (Table 1). Figure 4 shows the colony morphology on TSA medium and cell morphology observed by transmission electronic microscopy of strains P51 and P52. The three bacterial strains were grown in LB broth supplemented with simazine, reaching a turbidity $600 \mathrm{~nm} \sim 1.2$. Degradation of simazine by these strains grown in LB broth with simazine was studied using resting cell assays. The strains P51 and P52 degraded $>80 \%$ of simazine $(0.5 \mathrm{mM})$ within $48 \mathrm{hrs,}$ while strain C53 removed $>60 \%$ of this herbicide (Figure 5). The presence of the catabolic atz $A$ and atzD genes was analyzed by PCR-amplification using specific primers. The $a t z A$ and atzD genes encode the first enzyme of the upper and lower s- triazine catabolic pathways (Figure 3), respectively (Mandelbaum et al. 1995; Devers et al. 2007; Iwasaki et al. 2007). The atzA and $a t z D$ genes were detected in strains P51 and C53, while only atzD gene was observed in strain P52 (Table 2). The isolation of s-triazinedegrading bacteria has been reported, and atz genes have been determined in some of these isolates (Mandelbaum et al. 1995; Rousseaux et al. 2001; Devers et al. 2007).

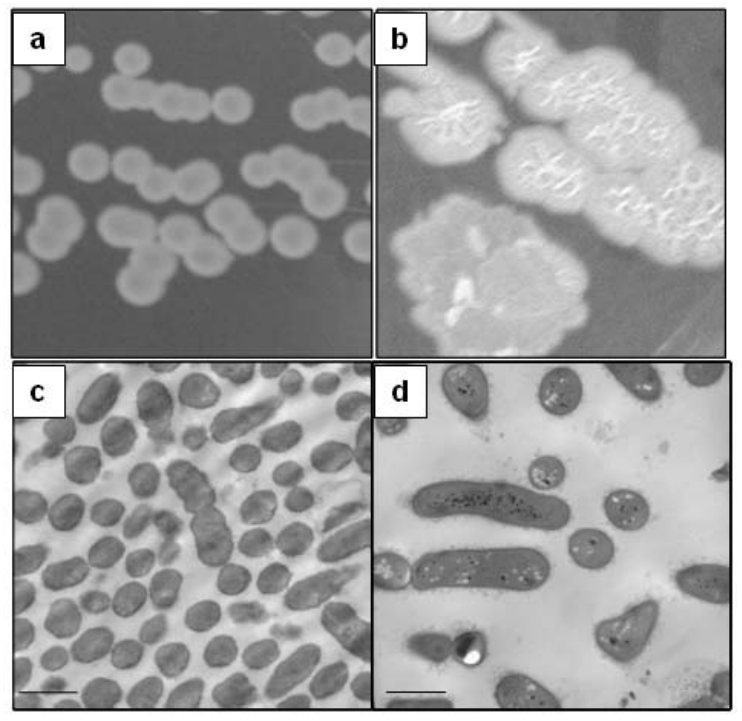

Figure 4. Colony and cell morphology of simazinedegrading bacterial strains.

(a) Stenotrophomonas sp. strain P51, colony morphology on TSA medium.

(b) Arthrobacter sp. strain P52, colony morphology on TSA medium.

(c) Stenotrophomonas sp. strain P51, bacterial morphology of cells grown in AM medium with simazine and observed by transmission electronic microscopy.

(d) Arthrobacter sp. strain P52, bacterial morphology of cells grown in AM medium with simazine and observed by transmission electronic microscopy. Bar represents $1 \mu \mathrm{m}$. 


\section{ARDRA}

To further characterize the isolates, comparative analysis of the 16S rRNA gene restriction pattern (ARDRA) of the three bacterial strains was performed. This method allows a fast analysis of the 16S rRNA gene sequence structure of bacterial strains. The PCR-amplified 16S rRNA genes of the three strains were digested using the restriction enzymes Msp1 and Hha1. The ARDRA profiles of P51 and C53 strains were similar, suggesting that they are closely related bacteria. ARDRA indicated that strain P52 is a different ribotype (Figure 6).

\section{Identification of simazine-degrading bacteria}

The 16S rRNA gene of the three isolates were sequenced and analyzed for bacterial identification. The strain C53 isolated from persimmon plantation and strain P51 isolated from avocado plantation soil were classified as Proteobacteria, class Gammaproteobacteria, order Xanthomonadales, family Xanthomonadaceae and were most similar to genus Stenotrophomonas, with a high sequence similarity (>98\%). Both strains C53 and P51 differ slightly in their 16S rRNA gene sequence. The strain P52 isolated from persimmon plantation soil was classified as Actinobacteria, class Actinobacteria, order Actinomycetales, family Micrococcaceae and was most similar to genus Arthrobacter with a similarity > 97\% (Table 2). s-Triazine-degrading bacterial strains belonging to other genera, such as Pseudomonas, Nocardioides and Agrobacterium, have also been reported (Mandelbaum et al. 1995; Devers et al. 2007; Hernández et al. 2008b).

\section{CONCLUDING REMARKS}

Three bacterial strains capable to degrade simazine and to use it as sole nitrogen source for growth were isolated from herbicide-treated agricultural soils of central Chile. These strains were characterized and identified. Resting cells of the strains P51, P52 and C53 were able to efficiently degrade simazine. The atz $A$ and $a t z D$ genes encoding the

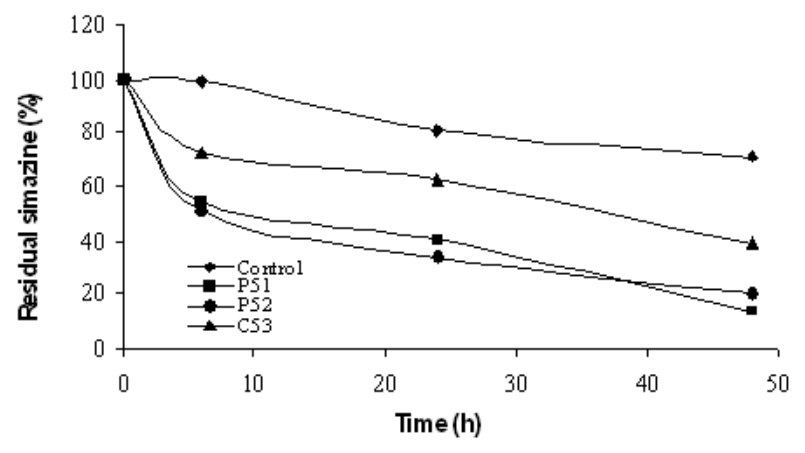

Figure 5. Simazine degradation by bacterial strains P51, P52 and C53. Resting cells of cultures previously grown in LB broth with simazine were incubated with simazine $(0.5 \mathrm{mM})$. Control: without cells. Each value is an average of two independent experiments.

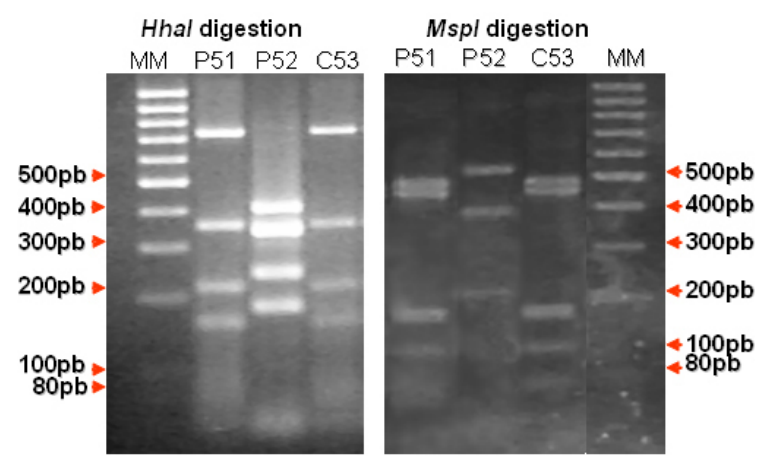

Figure 6. Amplified 16S rRNA gene restriction analysis of 3 isolated bacterial strains. The amplified 16S rRNA genes were digested with restriction enzymes Hhal and Mspl. DNA restriction patterns were observed in an agarose gel stained with ethidium bromide. MM: Molecular mass standards.

first enzyme of the upper and lower s-triazine catabolic pathways were detected in strains P51 and C53. The bacterial strain P52 possesses the atzD gene. ARDRA indicated that strain P52 is a different ribotype than strains C53 and P51. By sequence analysis of the 16S rRNA genes, strains C53 and P51 were identified as Stenotrophomonas sp. and strain P52 was identified as Arthrobacter sp. Further studies of these simazine-degrading bacteria are required to analyze their potential application as biocatalysts for bioremediation of environments contaminated with $s$-triazine herbicides.

\section{REFERENCES}

CÁMARA, Beatriz; HERRERA, Cristina; GONZÁLEZ, Myriam; COUVE, Eduardo; HOFER, Bernd and SEEGER, Michael. From PCBs to highly toxic metabolites by the biphenyl pathway. Environmental Microbiology, August 2004, vol. 6, no. 8, p. 842-850.

COOMAN, Katrien; DEBELS, Patrick; GAJARDO, Marisol; URRUTIA, Roberto and BARRA, Ricardo. Use of Daphnia spp. for the ecotoxicological assessment of water quality in an agricultural watershed in south-central Chile. Archives of Environmental Contamination and Toxicology, June 2005, vol. 48, no. 2, p. 191-200.

DE SOUZA, Mervyn L.; SEFFERNICK, Jennifer; MARTINEZ, Betsy; SADOWSKY, Michael J. and WACKETT, Lawrence P. The atrazine catabolism genes atzABC are widespread and highly conserved. Journal of Bacteriology, April 1998, vol. 180, no. 7, p. 1951-1954.

DEVERS, Marion; SOULAS, Guy and MARTINLAURENT, Fabrice. Real-time reverse transcription PCR analysis of expression of atrazine catabolism genes in two bacterial strains isolated from soil. Journal Microbiology Methods, January 2004, vol. 56, no. 1, p. 3-15. 
DEVERS, Marion; AZHARI, Najoi E.; KOLIC, NikolinaUdikovic and MARTIN-LAURENT, Fabrice. Detection and organization of atrazine-degrading genetic potential of seventeen bacterial isolates belonging to divergent taxa indicate a recent common origin of their catabolic functions. FEMS Microbiology Letters, August 2007, vol. 273, no. 1 , p. 78-86.

DINAMARCA, M. Alejandro; CERECEDA-BALIC, Francisco; FADIC, Ximena and SEEGER, Michael. Analysis of $s$-triazine-degrading microbial communities in soils using most-probable-number enumeration and tetrazolium-salt detection. International Microbiology, July 2007, vol. 10, p. 209-215.

European Union. The European Parliament and the Council of the European Union. Decision 2455/2001/EC, 2001, Brussels, Belgium.

Food and Agriculture Organization of the United Nations. FAO Statistic Division [online]. Updated 2008 [cited December 2006]. FAO, Rome, Italy. Available from Internet: http://faostat.fao.org/site/423/default.aspx\#ancor

HERNÁNDEZ, Marcela; MORGANTE, Verónica; FLORES, Cecilia; VILLALOBOS, Patricio; GONZÁLEZ, Myriam; MIRALLES, Pola; DINAMARCA, Alejandro and SEEGER, Michael. Modern approaches for the study of $s$ triazine herbicide bioremediation in agricultural soils. Journal of Soil Science and Plant Nutrition, September 2008a, vol. 8, no. 2, p. 19-30.

HERNÁNDEZ, Marcela; VILLALOBOS, Patricio; MORGANTE, Verónica; GONZÁLEZ, Myriam; REIFF, Caroline; MOORE, Edward and SEEGER, Michael. Isolation and characterization of a novel simazinedegrading bacterium from agricultural soil of central Chile, Pseudomonas sp. MHP41. FEMS Microbiology Letters, September 2008b, vol. 286, no. 2, p. 184-191.

IWASAKI, Akio; TAKAGI, Kazuhiro; YOSHIOKA, Yuichi; FUJII, Kunihiko; KOJIMA, Yuki and HARADA, Naoki. Isolation and characterization of a novel simazinedegrading $\beta$-proteobacterium and detection of genes encoding s-triazine-degrading enzymes. Pest Management Science, March 2007, vol. 63, no. 3, p. 261-268.

MANDELBAUM, Raphi T.; ALLAN, Deborah. L. and WACKETT, Lawrence P. Isolation and characterization of a Pseudomonas sp. that mineralizes the s-triazine herbicide atrazine. Applied and Environmental Microbiology, April 1995, vol. 61, no. 4, p. 1451-1457.

MARTINEZ, Betsy; TOMKINS, Jeffrey; WACKETT, Lawrence P.; WING, Rod and SADOWSKY, Michael J. Complete nucleotide sequence and organization of the atrazine catabolic plasmid pADP-1 from Pseudomonas sp. strain ADP. Journal of Bacteriology, October 2001, vol. 183, no. 19, p. 5684-5697.
MARTÍNEZ, Paula; AGULLÓ, Loreine; HERNÁNDEZ, Marcela and SEEGER, Michael. Chlorobenzoate inhibits growth and induces stress proteins in the PCB-degrading bacterium Burkholderia xenovorans LB400. Archives of Microbiology, September 2007, vol. 188, no. 3, p. 289-297.

NEWCOMBE, David A. and CROWLEY, David E. Bioremediation of atrazine-contaminated soil by repeated applications of atrazine-degrading bacteria. Applied Microbiology and Biotechnology, February 1999, vol. 51, no. 6 , p. $877-882$.

ROUSSEAUX, Sandrine; HARTMANN, Alain and SOULAS, Guy. Isolation and characterisation of new Gram-negative and Gram-positive atrazine degrading bacteria from different French soils. FEMS Microbiology Ecology, July 2001, vol. 36, no. 2-3, p. 211-222.

WACKETT, Lawrence P.; SADOWSKY, Michael J.; MARTINEZ, Betsy and SHAPIR, Nir. Biodegradation of atrazine and related s-triazine compounds: from enzymes to field studies. Applied Microbiology and Biotechnology, January 2002, vol. 58 , no. 1, p. 39-45. 